\title{
Hierarchy of Needs in Angie Thomas's Novel "The Hate U Give": Abraham Maslow
}

\author{
Nursaamah Lubis ${ }^{1)}$, Robby Satria ${ }^{2)}$ \\ ${ }^{1}$ Universitas Putera Batam \\ Pb171210020@upbatam.ac.id \\ ${ }^{2}$ Universitas Putera Batam \\ Robby@puterabatam.ac.id
}

\author{
Received: $17^{\text {th }}$ July 2021| Revised: $28^{\text {th }}$ July 2021| Accepted: $2^{\text {nd }}$ December 2021 \\ Email Correspondence: Pb171210020@upbatam.ac.id
}

\begin{abstract}
This research discusses hierarchy of needs in the novel "The Hate U Give" by Angie Thomas (2017) as the data source and using a psychological approach. In this research, researcher focused on what are the hierarchical needs in the novel "The Hate U Give" by Angie Thomas (2017). This research used descriptive qualitative by Creswell (2013) to analyze and with Maslow (1987) theory's of hierarchy of needs. The phenomenon of hierarchy of needs reflected in this novel occurred in Mississippi, America in 2010. This research shows the influence of hierarchy of needs experienced by the characters in the novel "The Hate U Give" by Angie Thomas (2017) such as; Physiological, Safety, Love/ belonging, Esteem, Self-actualization.
\end{abstract}

Key words: hierarchy, physiological, safety, love/belonging, esteem, self-actualization.

\section{INTRODUCTION}

The During this time of a pandemic, many people are doing activities at home, because of regulations that require everyone to maintain social distancing, which is intended to prevent the spread of the corona virus, known as social distancing (Pearce, 2020) This makes some people may feel bored, worried and introspective over social conditions during the social distancing period. This happens because of the natural instinct of humans in meeting their needs, namely the need for security, this need is also part of Abraham Maslow's (1987) hierarchy of needs. For those who like to be at home, maybe this is the right time to enjoy me time and self-reflect. For those who like to read books, this might be the right time to finish what they have read, whether it is fiction or non-fiction.

Online at https://journal.universitasbumigora.ac.id/index.php/humanitatis/

DOI : https://doi.org/10.30812/humanitatis.v8i1.1342 
Regarding reading social situations, how people cope with them, and reading books, there are many ways people try to express hierarchy of needs, be it from ordinary people, academics and so on. One of the clear evidence of this criticism can also be seen from the academic side, namely literature. This can be seen how writers try to describe, draw critical conclusions and provide solutions to the problem in society as individual or group can be expressed in writing and action, such as short stories, poetry, novels, dramas, films and so on.

Based on this, the researcher makes literature an interesting object to study. In this research, the researcher tries to peel and show the reader how psychology criticism is carried out in a literary work. In this study, the literary works that will be analyzed by the writer are Angie Thomas' novel, "The Hate U Give". This novel was released in 2017 with the theme of school children, family, social life and race, besides this novel is also set in Mississippi, America in 2010.

Specifically, this novel tells about the life of a teenager named Starr Carter who is a 16 year old student is attending an elite school dominated by the majority of white students. Meanwhile, on one side, Starr lives in a pretty shabby residential area on the outskirts of Mississippi, America. The places where he lived and attended school had quite a big difference, in that she could see how the white and black community looked at each other (intergroup perspective). Starr also felt both directly and indirectly how her friends or people in her school treated black people (students) with racist connotations. This makes Starr have to maintain her attitude and be able to determine the attitude to face her.

Starr plays the protagonist who tells the whole story in the novel based on her point of view. She started from how she lived her social life then spread to her school life and how the attitudes of the two communities (white and black people) looked at each other. An event that gives Starr a deep wound becomes the main topic of the story in this novel. The incident is about how Starr became the only witness of the killing of Khalil, who was Starr's little friend. This incident not only affected Starr but also affected everyone nationally, where the case of Khalil's murder sparked protests by the public and the government's attitude in dealing with it. From the background of the novel above, in this research, researcher focuses on how psychological state of a person experiences the impact of a thing using hierarchy of needs theory by Abraham Maslow Abraham Maslow (1987) that are contained in the novel "The Hate U Give" by Angie Thomas (2017).

This research analyzed by using the psychology approach with Hierarchy of needs theory by Abraham Maslow (1987). Although the novel "The Hate U Give" by Angie Thomas (2017) has a core theme of "Identity and darkness" which is related to postcolonial issues such as racism and

Online at https://journal.universitasbumigora.ac.id/index.php/humanitatis/

DOI : https://doi.org/10.30812/humanitatis.v8i1.1342 
discrimination, however, in this research, researcher analyzed the physiological side contained in the novel, which can be said to be interrelated with the main theme of the novel.

Every action can have an impact on the mental condition of a person whether they do or accept it. It has to do with psychology. Psychology itself is the science of behavior and thoughts, including the study of conscious and unconscious phenomena, as well as the feelings and thoughts of a person who are influenced by their internal and external circumstances (Hornby, 2015). Abraham Maslow with "Hierarchy of needs" theory discussing human motivation base on their hierarchy needs started lower laver until the top level of human dasher (level of human need) such as; Physiological, Safety, Love/ belonging, Esteem (the need to be respected), Self-actualization (Maslow, 1987).

\section{a. Physiological}

This is the most basic need for humans or the best needs as the requirement for human survival, if their requirement is not full fill human body cannot function, such as; food, water, oxygen, sex and so on (Maslow, 1987)

\section{b. Safety Needs}

The next need is the need for safety, where this happens if the physiological needs have been met. A human or a person would naturally seek such security; security, stability, dependency, freedom from fear, from anxiety, protection. Threatening mental conditions such as not being ridiculed, not humiliated, not stressed, and so on. The need for security differs from a physiological need in that it cannot be fully met. Humans can never be fully protected from the threats of meteors, fires, floods or the dangerous behavior of others. An insecure person has an excessive need for order and stability and will go to great lengths to avoid extraneous and unexpected things.(Maslow, 1987)

\section{c. Love and belonging}

A person will try to fulfill this need after the safety and physiological needs are met. The needs to be love, getting attention and affection be it from family, Friends or Lovers. If this need is not obtained or fulfilled, it can affect a person's behavior, both positive and negative (naughty children, cheating, etc.) (Maslow, 1987)

\section{d. Esteem needs}

The next need is Self-esteem, which is a condition where a person wants himself to be respected and respected by others or gets a good judgment from others on him. To be respected, accepted, and value by others, this is influenced by one's reputation, namely the higher one's position the higher the level of esteem (Maslow, 1987)

\section{e. Self- Actualization}

Online at https://journal.universitasbumigora.ac.id/index.php/humanitatis/

DOI : https://doi.org/10.30812/humanitatis.v8i1.1342 
The top level of human hierarchy of accept base on their talent and interest, it cannot begin before accomplishing the first four levels;

- Accomplishment

- Self development

- Ideology

- Maturity

The use of hierarchy of needs theory by Maslow (1987) in this research is very important. This is because this theory can be the basis for analyzing how the psychological state of a person experiences the impact of a thing. A person's mental state when or after experiencing something and how it affects them can be assessed using this theory. Based on this, the researcher finally decided to use this theory in analyzing the data, namely the novel "The Hate U Give" by Angie Thomas.

Previous research on psychology using Maslow's hierarchy of needs theory has been carried out, for example, the research conducted by Bayoumi (2012) which discusses the identification of the needs of hemodialysis patients using Maslow's hierarchy of needs concept which aims to identify the needs of patients undergoing maintenance hemodialysis. Using descriptive research methods conducted in the dialysis unit of the Suez Canal University Hospital. With the conclusion that the highest need of hemodialysis patients is self-esteem and the lowest is for love and belonging.

Other previous research is research using the same data source, namely the novel "The Hate U Give" has been discussed. For example like in the research's Jarrar. The researcher used the same data source in his research but different focus and theory. He reinforces racist in the novel which is how racism is depicted in real life and in America. The research used racism theory. The results of the research are showcase of the hatred that African Americans have received from the American society, the racism exists in every layer of American society and the last, the reaction and coverage of media might have portrayed the incident in a more sympathetic manner towards black people (Jarrar, 2020).

This research has similarity with first previous research, such as discussing hierarchy of needs, using the same theory of expect and in the second previous research has similarity like using same data source (novel). But, of course this research is also different from the first previous research that is the data source and in the second previous research the difference is this research which using different theory. This research focuses on the issue of hierarchy of needs experienced by the characters in the novel "The Hate U Give" by Angie Thomas (2017).

\section{RESEARCH METHOD}

Online at https://journal.universitasbumigora.ac.id/index.php/humanitatis/

DOI : https://doi.org/10.30812/humanitatis.v8i1.1342 
In this research, researcher used qualitative method in the process of collecting, analyzing and summarizing data. According to Creswell (2013) qualitative method itself is a research method used to analyze and identify questions such as phenomenological research, case studies and ethnography. By relating the phenomena that usually occur in everyday life, this is similar to that investigated in this study.

The results of the research will be explained in the form of words, phrases, sentences and paragraphs descriptively. The qualitative method itself provides a systematic, factual, and accurate description of the situation of the research object. In this study, researcher explains about psychology with hierarchy of needs theory by Maslow (1987) In the in the novel "The Hate U Give" by Angie Thomas (2017).

\section{FINDINGS AND DISCUSSION}

Basically, in every literary work there will always be things that show how each character tries to fulfill his or her needs or hierarchy of needs. Based on this, in this section the researcher will describe what "hierarchy of needs" is contained in the novel "The Hate U Give "by Angie Thomas (2017) based on Maslow theory's (1987)

\subsection{Physiological}

Finding work, and earning money is perhaps the best way to meet natural human needs, the best needs as the requirement for human survival, if their requirement is not full fill human body cannot function, such as; food, water, oxygen, sex and so on. This need is known as physiological needs by Maslow (1987). In this research the researcher will explain what physiological needs are contained in the novel "The Hate U Give" by Angie Thomas (2017)

In this novel, the researcher found data on the name of Starr's parents trying to restore Starr's appetite by offering him turkey bacon or regular. This is shown in the following quote;

"Momma opens the fridge, the door crowded with takeout menus and fruit- shaped magnets."All right, Munch," she says, "you want turkey bacon or regular?”

"Regular" I'm surprised I have an option. We never have pork. We aren't Muslims. More like "Christlims." Momma became a member of Christ Temple Church when she was In Nana's belly. Daddy believes in Black Jesus but follows the Black Panthers' TenPoint Program more than the Ten Commandments. He agrees with the Nation of Islam on some stuff, but he can't get over the fact that they may have killed Malcolm X." (Thomas, 2017 Chp 2. page 23)

In this data, after the shooting case of Khalil that took his life which was witnessed by Starr firsthand, it affected Starr's mental state, where she lost her appetite as a result of the sadness and shock

Online at https://journal.universitasbumigora.ac.id/index.php/humanitatis/

DOI : https://doi.org/10.30812/humanitatis.v8i1.1342 
that she experienced, when her mother offers them "Bacon" which they don't normally eat, it shows that her mother is trying to return Starr's lust so that Starr can meet her basic needs (eat). This is in accordance with the hierarchy of needs theory by Maslow (1987) that is physiological needs that is the best needs as the requirement for human survival, if their requirement is not full fill human body cannot function, such as; food, water, oxygen, sex and so on.

\subsection{Safety needs}

Living in a city or in a developed country, does not guarantee that everyone will always feel comfortable, of course there will be events that make people worry and try to get comfortable, this refers to safety needs that are need for security, stability, dependency, freedom from fear, from anxiety, protection. Threatening mental conditions such as not being ridiculed, not humiliated, not stressed, and so on.(Maslow, 1987)

In this novel, researcher found data where when the characters "Starr and Khalil" took refuge by fleeing when there was a shooting that occurred at the Big D's Spring day party to seek security, which is shown in the following quote;

\section{"Khalil grabs my hand "C'mon."}

There are way too many people and way too much curly hair for me to catch a glimpse of Kenya, "But Kenya-"

\section{"Forget her, let's go!"}

He pulls me through the crowd, shoving people out our way and stepping on shoes. That alone could get us some bullets. I look for Kenya among the panicked faces, but still no sign of her. I don't try to see who got shot or who did it. You can't snitch if you don't know anything.

Cars speed away outside, and people run into the night in any direction where shots aren't firing off. Khalil leads me to a Chevy Impala parked under a dim streetlight. He pushes me in through the driver's side, and I climb into the passenger seat. We screech off, leaving chaos in the rear view mirror." (Thomas, 2017 Chp 1. page 14)

In this first data, the way how Khalil grabs Starr's hand to leave the party so as not to be shot is proof that both of them need security, this is in accordance with the hierarchy of needs theory by Maslow (1987) that is safety needs that need for security, stability, dependency, protection, freedom from fear, from anxiety. Threatening mental conditions such as not being ridiculed, not humiliated, not stressed, and so on.

In the second data, researcher also founds the same thing where Starr tried to be calm so as not to cause problems that threatened their safety. This can be seen in the following quote;

Online at https://journal.universitasbumigora.ac.id/index.php/humanitatis/

DOI : https://doi.org/10.30812/humanitatis.v8i1.1342 


\section{'The other talk was about what to do if a cop stopped me.}

Momma fussed and told Daddy I was too young for that. He argued that I wasn't too young to get arrested or shot.

"Starr-Starr, you do whatever they tell you to do," he said. "Keep your hands visible. Don't make any sudden moves. Only speak when they speak to you."

I knew it must've been serious. Daddy has the biggest mouth of anybody I know, and if he said to be quiet, I needed to be quiet." (Thomas, 2017 Chp 2. page 17)

When Khalil and Starr left the Big D party, they were stopped on the way by a policeman, due to their status as black people and the issue of racism that had occurred, Starr's parents told them what to do when this happens to stay safe, because usually black people are vulnerable to unfair treatment, namely staying calm and following police orders. What Starr and Khalil have done proves that they need security, this is in accordance with the hierarchy of needs theory by Maslow (1987) that is safety needs that need for security, stability, dependency, protection, freedom from fear, from anxiety. Threatening mental conditions such as not being ridiculed, not humiliated, not stressed, and so on.

\subsection{Love and belonging}

The needs to be love, getting attention and affection are it from family, Friends or Lovers. If this need is not obtained or fulfilled, it can affect a person's behavior, both positive and negative (naughty children, cheating, etc.). Then, in this research the researcher will be explained what love and belonging needs are contained in this novel.

The fact that Starr comes from a black family and the acts of racism they receive make Starr's father forbid Starr from dating white people, but the fact is that Starr has a white girlfriend named Chris as stated in this quote "I'm not happy with Chris, yet I miss him. I miss us. I need him so much that I'm willing to forget what he did. That's scary as fuck too. Someone I've only been with for a year means that much to me? But Chris...he's different." (Thomas, 2017 Chp 5. page 50)

In this data, even though Starr realizes that she is being opposed by her father, Starr continues her relationship even when admitting that she misses her boyfriend when they are having problems, this shows that Starr wants to be loved and to love someone. This is in accordance with the hierarchy of needs theory by Maslow (1987) that is love and belonging that is the needs to be love, getting attention and affection be it from family, friends or lovers.

\section{CONCLUSION}

The novel "The Hate U Give" by Angie Thomas (2017) has a main theme about post-colonial issues such as racism, discrimination and so on, but what the characters experience about it also affects their needs and how to fulfill them. In this paper, the researcher used to analyze the novel using Hierarchy

Online at https://journal.universitasbumigora.ac.id/index.php/humanitatis/

DOI : https://doi.org/10.30812/humanitatis.v8i1.1342 
of Needs by Abraham Maslow. In this theory, there are five needs; physiological needs, safety needs, love and belonging, esteem and self-actualization. In the novel "The Hate U Give" by Angie Thomas (2017), the researcher used to analyze until love and belonging.

Humans are required to be wise in making decisions, not only for themselves but also for other people. Wisdom will bring people into a peaceful life, while decisions made only because of one's own desire without thinking about the circumstances will only have bad effects not only for self but for others as well.

\section{REFERENCES}

Bayoumi, M. (2011). Identification of the needs of haemodialysis patients using the concept of Maskow's hierarchy of needs. Ournal of Renal Care, 38(1), 43-49. https://doi.org/https://doi.org/10/1111/j.1755-6686.2011.00237.x

Creswell, J. W. (2013). Research design qualitative, quantitative, and mixed method approaches (4th ed; V. Knight, ed.). Retrieved from http://libgen.li/item/index.php?md5=A000CDF97760A63A36F28A042A568EE5

Hornby, A. S. (2015). Oxford advanced learner's dictionary international student edition (9th ed.; suzannee holloway Hey Leonie, ed.). Retrieved from www.oxfordlearnerdictionaries.com

Jarrar, D. S. M. (2020). The hate u give: As you are black, you have no rights. European Journal of English Language and Literature Studies, 8(1), 37-41. Retrieved from https://www.eajournals.org/wp-content/uploads/The-Hate-U-Give.pdf

Maslow, A. H. (1987). Motivation and personality (3rd ed.). Retrieved from http://gen.lib.rus.ec/book/index.php?md5=509d5764b305d7f349087808ddc7ab88

Pearce, K. (2020). What is social distancing abd how can it slow the speread of covid-19? Retrieved July 15, 2021, from https://hub.jhu.edu/2020/03/13/what-is-social-distancing/

Thomas, A. (2017). The hate $U$ give. Retrieved from www.walker.co.uk

Online at https://journal.universitasbumigora.ac.id/index.php/humanitatis/

DOI : https://doi.org/10.30812/humanitatis.v8i1.1342 